\title{
PEMBAHARUAN HUKUM PERJANJIAN SPORTENTERTAINMENT BERBASIS NILAI KEADILAN (Studi Kasus Pada Petinju Profesional di Indonesia)
}

\author{
Hananto Prasetyo \\ Pengusaha di Semarang \\ hanantoprasetyo@yahoo.co.id
}

\begin{abstract}
This paper aims to examine the weakness that exist in the sportentertainment agreement between professional boxers and current managers. This study is included in the sociological juridicial study due to existence of field activities to find out the real situation in the field. The conceptual framework begins with the emergence of a lack fair sense of the boxer in his profession as an athlete. Primary data source from the interview result plunged into the field with the responses of professional athletes, while the secondary data sources are references related to the title, such as legislation relating to the agreement as well as bibliographic references. While data analysis using content analysis. The results indicate there is still much execution of agreement between professional athletes and managers who harmed the athlete due to lack of understanding of the agreement law.
\end{abstract}

Keywords : sportentertainment agreement, reconstruction of law, justice.

\begin{abstract}
Abstrak
Tulisan ini bertujuan untuk mengkaji kelemahan-kelemahan yang ada dalam perjanjian sportentertainment antara petinju profesional dan manajer yang ada saat ini. Kajian ini termasuk dalam kajian yuridis sosiologis disebabkan adanya kegiatan terjun ke lapangan untuk mengetahui keadaan riil di lapangan. Kerangka konsepnya berawal dari timbulnya ketiadaan rasa yang adil bagi petinju dalam menjalani profesinya sebagai atlet. Sumber data primer dari hasil wawancara terjun ke lapangan dengan responsen para atlet petinju profsional, sedangkan sumber data sekunder berupa referensi yang berhubungan dengan judul, diantaranya peraturan perundangundangan yang berkaitan dengan perjanjian serta referensi kepustakaan. Sedangkan analisis data menggunakan analisis isi (content analysis). Hasilnya menunjukkan masih banyak pelaksanaan perjanjian antara atlet petinju profesional dengan manajer yang merugikan pihak atlet karena kurangnya pemahaman hukum perjanjian.
\end{abstract}

Kata kunci : perjanjian sportentertainment, pembaharuan hukum, keadilan.

\section{A. Pendahuluan}

Di Indonesia sportentertainment makin mendapat perhatian serius, baik dari kalangan pemerintah, olahragawan, maupun masyarakat luas yang bergairah untuk menonton maupun mengikuti perkembangannya melalui media cetak maupun elektronik salah satunya tinju profesional. Petinju sebaiknya terikat perjanjian kerja dengan manajer sasana, sehingga untuk perpindahan petinju dapat diatur secara administrasi yang tidak akan merugikan kedua belah pihak. Di dalam Pasal 1313 Kitab Undang-Undang Hukum
Perdata (KUHPerdata), memberikan suatu batasan atau definisi mengenai perjanjian atau persetujuan yaitu: "Suatu persetujuan adalah suatu perbuatan dengan mana satu orang atau lebih mengikatkan dirinya terhadap satu orang lain atau lebih".

Perjanjian yang sah artinya adalah persetujuan yang memenuhi syarat-syarat yang telah ditentukan oleh undang-undang, sehingga ia diakui oleh hukum. ${ }^{1}$ Sesuai bimbingan dan pengarahan

Abdul Kadir Muhammad, 1982, Hukum Perikatan, Alumni, Bandung, hlm.88 
dari Menteri Pemuda dan Olah Raga Republik Indonesia, maka Indonesia berhasil melahirkan juara-juara dunia antara lain Chris John yang telah berhasil mangangkat derajat bangsa Indonesia di mata dunia Internasional. Namun demikian tidak dapat dipungkiri bahwa kegiatan yang dilaksanakan, terutama penyelenggaraan pertandingan tidak dapat berjalan sebagaimana mestinya apabila tidak ada komponen penunjangnya. Adapun komponen penunjang yang merupakan pelakupelaku utama dari kegiatan pertandingan tinju profesional tersebut adalah: Petinju. Manajer. Promotor. Corps Wasit. Sponsor/ penyandang dana.

Dalam pelaksanaan perjanjian kadangkala mengalami hambatan, artinya isi perjanjian tidak dapat dilaksanakan. Hal ini dapat terjadi karena salah satu pihak ingkar janji atau wanprestasi atau keduanya ingkar janji. Perjanjian antara Petinju dengan Manajer Tinju Profesional yang dimaksudkan adalah antara petinju Profesional Christian John dengan manajer sasana Bank Buana Semarang Muchlis Sutan Rambing terdapat klausula dalam Pasal 1 sub 4 yang menyatakan Pihak Pertama selaku Pemilik Sasana Tinju Bank Buana Semarang adalah sebagai pihak yang secara hukum memiliki hak atas diri Pihak Kedua selaku atlet binaannya.

Di dalam Pasal 1313 Kitab Undang-Undang Hukum Perdata (KUHPerdata), memberikan suatu batasan atau definisi mengenai perjanjian atau persetujuan yaitu: "Suatu persetujuan adalah suatu perbuatan dengan mana satu orang atau lebih mengikatkan dirinya terhadap satu orang lain atau lebih". Dengan demikian perjanjian itu menerbitkan suatu perikatan antara dua pihak yang membuatnya atau dapat dikatakan pula, bahwa perjanjian adalah sumber perikatan disamping sumber-sumber lain.

Pasal 1338 ayat (3) KUHPerdata suatu perjanjian harus didasarkan atas asas itikad baik. Itikad baik dapat dibedakan menjadi itikad baik subjektif dan itikad baik objektif. Itikad baik subjektif, yaitu apakah yang bersangkutan sendiri menyadari bahwa tindakannya bertentangan dengan itikad baik, sedang itikad baik objektif adalah kalau pendapat umum menganggap tindakan yang demikian adalah bertentangan dengan itikad baik.
Berdasarkan asas konsensualitas yang terkandung dalam Pasal 1320 KUHPerdata, yaitu suatu perjanjian lahir pada detik tercapainya kesepakatan atau pesetujuan antara kedua belah pihak mengenai hal-hal yang pokok tentang apa yang menjadi obyek perjanjian. Berpedoman pada asas konsensualitas tersebut, maka untuk menentukan apakah telah lahir suatu perjanjian dan kapan perjanjian itu lahir, harus mengetahui apakah telah terjadi kesepakatan dan kapan kesepakatan itu terjadi. Berkaitan dengan perjanjian dalam Kitab Undang-Undang Hukum Perdata diatur dalam Pasal 1313, dimana dalam perjanjian ada kesepakatan antara kedua belah pihak, dan tidak diperkenankan ada pihak yang dirugikan.

Tulisan ini menggunakan metode pendekatan yuridis sosiologis. Sumber data yang digunakan dalam penelitian ini meliputi data sekunder dan primer. Data sekunder terdiri dari bahan hukum primer dan hukum sekunder serta menggunakan bahan hukum tersier, data studi pustaka dan literatur dan dokumen dari internet. Data sekunder dari bahan hukum primer yaitu dari perundangundangan yang berlaku dan mengikat mengenai peraturan hukum di Indonesia. Sedangkan bahan hukum sekunder yaitu bahan hukum yang memberikan penjelasan mengenai bahan hukum primer, sedangkan bahan hukum tersier yaitu bahan hukum yang memberikan petunjuk maupun penjelasan bahan baku hukum primer dan sekunder.

Metode pengumpulan data menggunakan kumpulan dari setudi kepustakaan, obeservasi lapangan serta wawancara bebas terpimpin. Pengumpulan data dilakukan dengan melakukan wawancara terlebih dahulu dengan Muclis Sutan Rambing selaku manajer, pemilik Sasana Tinju Bank Buana Semarang, melakukan telaah mendalam mengenai perjanjian antara kedua belah pihak, serta mengkomparasikan antara teori dan praktek kususnya Pasal 1320 KUHPer dan direkonstruksi kembali melalui pendapat para ahli dan litaeratur lainnya sehingga didapatkan hasil Pasal 1320 KUHPer yang berbasis nilai keadilan. Adapun mengenai lokasi penelitian disertasi ini dilakukan di Sasana Tinju Bank Buana Semarang.

Secara spesifik tulisan ini mengacu pada beberapa hal, yaitu bagaimana kelemahan- 
kelemahan dalam perjanjian sportentertainment antara petinju profesional dengan manajer saat ini? Serta bagaimana pembaharuan hukum perjanjian sportentertainment ke depan yang berbasis nilai keadilan? Yang bertujuan untuk mencari solusi dari kelemahan-kelamahan yang ada selama ini dalam perjanjian sportentainment antara petinju profesional dengan manajer, serta mencari ide pembaharuan dalam perjanjian hukum sportentertainment ke depan.

\section{B. Hasil Penelitian dan Pembahasan}

1. Pengertian Perjanjian dan Unsur-Unsur Perjanjian

Perjanjian diatur dalam Kitab UndangUndang Hukum Perdata (KUH Perdata) Pasal 1313, bahwa perjanjian atau persetujuan adalah suatu perbuatan dengan mana satu orang atau lebih mengikatkan dirinya terhadap satu orang lain atau lebih. Kata persetujuan tersebut merupakan terjemahan dari perkataan overeekomst dalam bahasa Belanda. Kata overeekomst tersebut lazim diterjemahkan juga dengan kata perjanjian. Jadi persetujuan dalam Pasal 1313 KUH Perdata tersebut sama artinya dengan perjanjian.

Perjanjian adalah perbuatan hukum berdasarkan kata sepakat untuk menimbulkan suatu akibat hukum. Hal itu sependapat pula dengan Sudikno, "perjanjian merupakan hubungan hukum antara dua pihak atau lebih berdasar kata sepakat untuk menimbulkan suatu akibat hukum".

Dalam perkembangan doktrin ilmu hukum dikenal adanya tiga unsur dalam Perjanjian. Unsur-unsur tersebut diuraikan sebagai berikut :

a. Unsur esensialia, adalah unsur yang harus ada dalam suatu perjanjian, karena jika tidak ada unsur ini maka perjanjian tidak ada.

b. Unsur naturalia, adalah unsur yang telah diatur dalam undang-undang, sehingga jika tidak diatur oleh para pihak dalam perjanjian, maka undangundang yang mengaturnya.

c. Unsur aksidentalia, adalah unsur yang nanti ada atau mengikat para pihak jika para pihak memperjanjikannya.
Demikian pula klausul-kalusul lainnya yang sering ditentukan dalam perjanjian, yang bukan merupakan unsur esensial dalam perjanjian.

Azas-azas hukum perjanjian meliputi:

1. Azas Konsensualitas, yaitu bahwa suatu perjanjian dan perikatan yang timbul telah lahir sejak detik tercapainya kesepakatan, selama para pihak dalam perjanjian tidak menentukan lain. Azas ini sesuai dengan ketentuan Pasal 1320 KUH Perdata mengenai syaratsyarat sahnya perjanjian.

2. Azas Kebebasan Berkontrak, yaitu bahwa para pihak dalam suatu perjanjian bebas untuk menentukan materi/isi dari perjanjian sepanjang tidak bertentangan dengan ketertiban umum, kesusilaan dan kepatutan. Azas ini tercermin jelas dalam Pasal 1338 KUH Perdata yang menyatakan bahwa semua perjanjian yang dibuat secara sah mengikat sebagai undang-undang bagi mereka yang membuatnya.

2. Perjanjian Sportentertainment Antara Manajer dan Petinju Profesional

Kontrak (perjanjian) adalah suatu peristiwa dimana seorang berjanji kepada orang lain atau dimana dua orang itu saling berjanji untuk malaksanakan suatu hal. Pengaturan Kontrak diatur dalam Buku III KUHPerdata, mengatur mengenai perikatan yang timbul dari perjanjian, serta mengatur perikatan yang timbul dari undang-undang misalnya tentang perbuatan melawan hukum. Dalam KUHPerdata terdapat aturan umum yang berlaku untuk semua perjanjian dan aturan khusus yang berlaku hanya untuk perjanjian tertentu yang namanya sudah diatur dalam undang-undang.

Dalam perjanjian berlaku asas kebebasan berkontrak, artinya pihak-pihak bebas untuk membuat kontrak/perjanjian apapun, baik yang sudah ada pengaturannya maupun yang belum ada pengaturannya dan bebas 
menentukan sendiri isi kontrak. Buku III KUHPerdata yang menganut sistem terbuka, berkedudukan sebagai hukum pelengkap dalam arti ketentuan-ketentuan dari Buku III KUHPerdata tersebut berlaku apabila para pihak dalam perjanjian tidak membaut ketentuan sendiri. Selain itu hukum perjanjian yang merupakan bagian dari hukum perikatan dikenal suatu asas yang disebut kebebasan berkontrak, asas ini dapat disimpulkan dari ketentuan Pasal 1338 Ayat (1) KUHPerdata yang berbunyi: "Semua perjanjian yang dibuat secara sah berlaku sebagai undang-undang bagi mereka yang membuatnya".

Dari pasal di atas dapat diartikan bahwa yang disebut dengan asas kebebasan berkontrak adalah suatu asas dalam hukum perjanjian yang memberikan kebebasan berkontrak adalah suatu asas dalam hukum perjanjian yang memberikan kebebasasan seluas-luasnya kepada masyarakat untuk mengadakan perjanjian yang berisi apa saja dan mengatur sendiri perjanjian yang akan mengikat pembuatnya dengan pembatasan yaitu tidak bertentangan dengan undangundang, kesusilaan, dan ketertiban umum (Pasal 1337 KUHPerdata).

Aspek-aspek kebebasan berkontrak dalam pasal $1338 \mathrm{KUHPerdata}$ (BW), yang menyiratkan adanya 3 (tiga asas) yang seyogyanya dalam perjanjian:

1. Mengenai Terjadinya Perjanjian

2. Tentang Akibat Perjanjian

3. Tentang Isi Perjanjian

\section{Perjanjian Sportentertainment Antara Petinju Profesional Dengan Manager Saat Ini.}

Dalam hukum privat, subyek hukumnya yaitu individu atau badan hukum, sementara subjek perjanjian dalam lapangan hukum publik adalah subjek hukum internasional yaitu negara, organisasi internasional dan gerakan-gerakan pembebasan. Tujuan utama pembentukan aturan tersebut yaitu menciptakan modifikasi atau perubahan yang sah secara hukum.

Penting untuk mengetahui perbedaan perikatan dan perjanjian pada dasarnya perikatan ialah suatu hubungan hukum antara dua pihak, dimana pihak yang satu berhak menuntut sesuatu hal dari pihak lain dan yang lain berkewajiban memenuhi tuntutan tersebut.

\section{a. Dilihat dari Hukum Privat}

Perbuatan hukum dalam perjanjian merupakan perbuatan-perbuatan untuk melaksanakan sesuatu, yaitu memperoleh seperangkat hak dan kewajiban yang disebut prestasi. Prestasi itu meliputi perbuatan-perbuatan:

1) Menyerahkan sesuatu, misalnya melakukan pembayaran harga barang dalam perjanjian jual beli barang.

2) Melakukan sesuatu, misalnya menyelesaikan pembangunan jembatan dalam perjanjian pemborongan pekerjaan.

3) Tidak melakukan sesuatu, misalnya tidak bekerja di tempat lain selain perusahaan tempatnya bekerja dalam perjanjian kerja.

Suatu perjanjian sedikitnya ada dua pihak yang saling memberikan kesepakatan, maka dimungkinkan terjadi suatu interaksi antar keduanya. Selain orang-perorangan (manusia secara biologis), para pihak dalam perjanjian bisa juga terdiri dari badan hukum. Perseroan Terbatas (PT) merupakan badan hukum yang dapat menjadi salah satu pihak atau keduanya dalam perjanjian. Kedua-duanya merupakan subyek hukum, yaitu pihak-pihak yang dapat melakukan perbuatan hukum, pihak-pihak yang mengemban hak dan kewajiban.

Hubungan hukum para pihak merupakan sebuah fakta hukum, yang dengan fakta itu kesalahpahaman dalam sengketa dapat diluruskan bagaimana seharusnya hubungan itu dilaksanakan dan siapa yang melanggar. Pengertian perjanjian ini mengandung unsur:
a. Perbuatan
Pemakaian kata "Perbuatan" pada rumusan tentang perjanjian 
ini lebih tepat bila diganti dengan kata "perbuatan hukum"atau "tindakan hukum", sebab perbuatan tersebut memiliki akibat hukum bagi para pihak yang memperjanjikan.

b. Satu orang atau lebih terhadap satu orang lain atau lebih

Untuk membuat sebuah perjanjian, paling sedikit harus ada dua pihak yang saling berhadaphadapan dan saling memberikan pernyataan yang cocok/pas satu sama lain. Pihak tersebut ialah orang atau badan hukum.

c. Mengikatkan dirinya

Dalam perjanjian terdapat unsur janji yang diberikan oleh pihak yang satu kepada pihak yang lain. Dalam perjanjian ini orang terikat kepada akibat hukum yang muncul karena kehendaknya sendiri.

a) Syarat sahnya Perjanjian

Syarat sahnya perjanjian adalah syarat-syarat agar perjanjian itu sah dan punya kekuatan mengikat secara hukum. Supaya suatu perjanjian bisa menjadi sah dan mengikat para pihak, perjanjian mesti memenuhi syaratsyarat seperti ditetapkan dalam Pasal 1320 KUH Perdata yaitu:

1) Syarat Subyektif (Mengenai subyek atau para pihak)

(a) Sepakat mereka yang mengikatkan dirinya Kata "sepakat" tidak boleh dikarenakan adanya kekhilafan mengenai hakekat barang yang menjadi pokok persetujuan atau kekhilafan mengenai diri pihak lawannya dalam persetujuan yang dibuat terutama mengingat dirinya orang tersebut, adanya paksaan dimana seseorang melakukan perbuatan karena takut ancaman (Pasal 1324 BW), adanya penipuan yang tidak hanya mengenai kebohongan tetapi juga adanya tipu muslihat (Pasal 1328 BW). Terhadap perjanjian yang dibuat atas dasar "sepakat" berdasarkan alasanalasan tersebut, dapat diajukan pembatalan.

(b) Cakap untuk membuat perikatan

Para pihak mampu membuat suatu perjanjian. Dalam hal ini kata "mampu"adalah para pihak telah dewasa, tidak dibawah pengawasan karena perilaku yang tidak stabil dan bukan orang-orang yang dalam Undangundang dilarang membuat suatu perjanjian. Pasal $1330 \mathrm{KUH}$ Perdata menentukan yang tidak cakap untuk membuat perikatan:

1. Orang-orang yang belum dewasa

2. Mereka yang ditaruh dibawah pengampuan

3. Orang-orang perempuan, dalam hal-hal yang ditetapkan oleh Undang-undang, dan pada umumnya semua orang kepada siapa Undang-undang telah melarang membuat perjanjian-perjanjian tertentu.

2) Syarat obyektif

a) Suatu hal tertentu

Perjanjian mesti menentukan jenis objek yang diperjanjikan. Bila tidak, maka perjanjian itu batal demi hukum. Pasal 1332 BW menentukan hanya barang-barang yang dapat diperdagangkan yang dapat menjadi obyek perjanjian, dan berdasarkan Pasal 1334 BW barang-barang yang baru akan ada di kemudian hari dapat menjadi obyek perjanjian kecuali jika dilarang oleh undang-undang secara tegas.

b) Suatu sebab atau kausa yang halal

Sahnya kausa dari suatu persetujuan ditentukan pada saat perjanjian dibuat. Perjanjian tanpa kausa yang halal ialah batal demi 
hukum, kecuali ditentukan lain oleh Undang-undang. ${ }^{2}$ Syarat pertama dan kedua menyangkut subyek, sedangkan syarat ketiga dan keempat mengenai obyek. Terdapatnya cacat kehendak (keliru, paksaan, penipuan) atau tidak cakap untuk membuat perikatan, mengenai subyek mengakibatkan perjanjian dapat dibatalkan. Selain itujika syarat ketiga dan keempat mengenai obyek tidak terpenuhi, maka perjanjian batal demi hukum. Contoh: Dalam melakukan perjanjian pengadaan barang, antara TPK (Tim Pelaksana Kegiatan) dengan suplier, maka harus memenuhi unsur-unsur:

1. TPK sepakat untuk membeli sejumlah barang dengan biaya tertentu dan supplier sepakat untuk menyuplai barang dengan pembayaran tersebut. Tidak ada unsur paksaan terhadap kedua belah pihak.

2. TPK dan supplier telah dewasa, tidak dalam pengawasan atau karena perundangundangan, tidak dilarang untuk membuat perjanjian.

3. Barang yang akan dibeli/ disuplai jelas, apa, berapa dan bagaimana.

4. Tujuan perjanjian jual beli tidak dimaksudkan untuk rekayasa atau untuk kejahatan tertentu (contoh: TPK dengan sengaja bersepakat dengan supplier untuk membuat kwitansi dimana nilai harga lebih besar dari harga sesungguhnya).

Dari uraian di atas, timbul satu

2 Halal, dalam perjanjian disini merupakan suatu hal yang cukup umum dimana definisi halal tidak hanya berdasarkan pada asas Islam, melainkan adanya maksud dari para pihak untuk berbuat baik dalam menjalankan isi dari perjanjian tersebut. pertanyaan, bagaimana jika salah satu syarat di atas tidak terpenuhi. Ada dua akibat yang dapat terjadi jika suatu perjanjian tidak memenuhi syarat di atas. Dalam Pasal 1331 (1) KUH Perdata, semua perjanjian yang dibuat secara sah berlaku sebagai Undang-undang bagi mereka yang membuatnya. Jika perjanjian yang dilakukan obyek/perihalnya tidak ada atau tidak didasari pada itikad yang baik, maka dengan sendirinya perjanjian tersebut batal demi hukum. Dalam kondisi ini perjanjian dianggap tidak pernah ada.

Sedangkan perjanjian yang tidak memenuhi unsur subyektif seperti perjanjian dibawah paksaan dan atau terdapat pihak dibawah umur atau dibawah pengawasan, maka perjanjian ini dapat dimintakan pembatalan (kepada hakim) oleh pihak yang tidak mampu termasuk wali atau pengampunya. Dengan kata lain, apabila tidak dimintakan pembatalan maka perjanjian tersebut tetap mengikat para pihak.

b. Akibat Perjanjian

Dalam pasal 1338 ayat (1) KUH Perdata, yang menyatakan bahwa semua kontrak (perjanjian) yang dibuat secara sah berlaku sebagai Undang-undang bagi mereka yang membuatnya. Suatu perjanjian tidak dapat ditarik kembali selain dengan sepakat kedua belah pihak, atau karena alasan-alasan yang oleh Undang-undang dinyatakan cukup untuk itu. Perjanjian tidak hanya mengikat untuk hal-hal yang dengan tegas dinyatakan didalamnya, namun juga untuk segala sesuatu yang menurut sifat perjanjian, diharuskan oleh kepatutan, kebiasaan atau undang-undang.

c. Berakhirnya Perjanjian

Perjanjian berakhir karena:

1) Ditentukan oleh para pihak berlaku untuk waktu tertentu; 
2) Undang-undang menentukan batas berlakunya perjanjian;

3) Para pihak atau undangundang menentukan bahwa dengan terjadinya peristiwa;

4) Tertentu maka persetujuan akan hapus.

Peristiwa tertentu yang dimaksud ialah keadaan memaksa (overmacht) yang diatur dalam Pasal 1244 dan 1245 KUHPerdata.

\section{b. Dilihat dari Hukum Publik}

Dalam Hukum Publik, "perjanjian" disini menunjuk kepada "Perjanjian Internasional". Saat ini pada masyarakat internasional, perjanjian internasional memainkan peranan yang sangat penting dalam mengatur kehidupan dan pergaulan antar negara.

a) Syarat sahnya perjanjian

Berbeda dengan perjanjian dalam hukum privat yang sah dan mengikat para pihak sejak adanya kata sepakat, namun dalam hukum publik kata sepakat hanya menunjukkan kesaksian naskah perjanjian, bukan keabsahan perjanjian. Selain itu setelah perjanjian itu sah, tidak serta merta mengikat para pihak apabila para pihak belum melakukan ratifikasi. Tahapan pembuatan perjanjian meliputi:

1) Perundingan dimana negara mengirimkan utusannya ke suatu konferensi bilateral maupun multilateral

2) Penerimaan naskah perjanjian (adoption of the text) adalah penerimaan isi naskah perjanjian oleh peserta konferensi yang ditentukan dengan persetujuan dari semua peserta melalui pemungutan suara

3) Kesaksian naskah perjanjian (authentication of the text), merupakan suatu tindakan formal yang menyatakan bahwa naskah perjanjian tersebut telah diterima konferensi

4) Pasal 10 Konvensi Wina, dilakukan menurut prosedur yang terdapat dalam naskah perjanjian atau sesuai dengan yang telah diputuskan oleh utusan-utusan dalam konferensi. Kalau tidak ditentukan maka pengesahan dapat dilakukan dengan membubuhi tanda tangan atau paraf di bawah naskah perjanjian

Persetujuan mengikatkan diri (consent to the bound), diberikan dalam bermacam cara tergantung pada permufakatan para pihak pada waktu mengadakan perjanjian, dimana cara untuk menyatakan persetujuan

b) Akibat perjanjian

$>$ Bagi negara pihak

Pasal 26 Konvensi Wina menyatakan bahwa tiaptiap perjanjian yang berlaku mengikat negara-negara pihak dan harus dilaksanakan dengan itikad baik atau in good faith. Pelaksanaan perjanjian itu dilakukan oleh organ-organ negara yang harus mengambil tindakan yang diperlukan untuk menjamin pelaksanaannya. Daya ikat perjanjian didasarkan pada prinsip pacta sunt servanda.

$>$ Bagi negara lain

Lain dengan perjanjian dalam lapangan hukum privat yang tidak boleh menimbulkan hak dan kewajiban bagi pihak ketiga, perjanjian internasional dapat menimbulkan akibat bagi pihak ketiga atas persetujuan mereka, dapat memberikan hak kepada negara-negara ketiga atau mempunyaiakibat pada negara ketiga tanpa persetujuan negara tersebut (contoh: Pasal 2 (6) Piagam PBB yang menyatakan 
bahwa negara-negara bukan anggota PBB harus bertindak sesuai dengan asas PBB sejauh mungkin bila dianggap perlu untuk perdamaian dan keamanan internasional).

c) Berakhirnya perjanjian

a. Sesuai dengan ketentuan perjanjian itu sendiri

b. Atas persetujuan kemudian yang dituangkan dalam perjanjian tersendiri

c. Akibat peristiwa-peristiwa tertentu yaitu tidak dilaksanakannya perjanjian, perubahan kendaraan yang bersifat mendasar pada negara anggota, timbulnya norma hukum internasional yang baru, perang.

\section{Perjanjian Kerja Antara Petinju Profesional dan Manajer}

a. Hubungan Kerja Petinju Profesional dan Manajer

Berdasarkan Pasal 51 Undangundang Nomor 13 Tahun 2003 perjanjian kerja dapat dibuat secara lisan maupun tulisan. Sedangkan dalam Pasal 54 ayat (1) Undang-undang Nomor 13 Tahun 2003, perjanjian kerja yang dibuat secara tertulis sekurang kurangnya memuat:

1) nama, alamat perusahaan, dan jenis usaha

2) nama, jenis kelamin, umur, dan alamat pekerja/ buruh

3) jabatan atau jenis pekerjaan

4) tempat pekerjaan dilakukan

5) besarnya upah dan cara pembayarannya

6) syarat-syarat kerja yang memuat hak dan kewajiban pengusaha dan pekerja/ buruh

7) mulai dan jangka waktu berlakunya perjanjian kerja

8) tempat dan tanggal perjanjian kerja dibuat

9) tanda tangan para pihak dalam perjanjian kerja b. Pemutusan Hubungan Kerja (PHK) Petinju Profesional dan Manajer

Berdasarkan Pasal 154 Undangundang Nomor 13 Tahun 2003 keputusan LPPHI tidak diperlukan apabila:

1) Pekerja yang dimaksud masih dalam masa percobaan dan telah diatur secara tertulis sebelumnya

2) Pekerja yang dimaksud membuat permohonan pengunduran diri dengan kemauanya sendiri tanpa adanya indikasi adanya tekanan atau intimidasi dari pemberi kerja untuk melakukanya atau hubungan kerja telah berakhir

3) Pekerja yang dimaksud telah mencapai usia pensiun yang diatur pada perjanjian kerja, peraturan perusahaan, perjanjian kerja bersama dan peraturan perundangaan

4) Pekerja meninggal dunia

c. Profesional Perjanjian Petinju

Profesional dan Manajer

Seorang profesional adalah seseorang yang gairah kerjanya sangat mengagumkan. la adalah seorang yang realistis, yang menyadari kemungkinannya membuat kesalahan. Akan tetapi ia cukup bijaksana pula untuk tidak membuat kesalahan yang sama sampai dua kali.Aturan serta pandangan tersebut lebih bersifat regulatif dan konstruktif. Seringkali kita keliru atau bahkan sedikit menyamakan makna profesional dengan profesi. Pada dasarnya kata dasar dari profesional ialah profesi maka wajar jika kebanyakan orang mengaitkannya. Akan tetapi makna dari kedua kata tersebut berbeda.

Profesi adalah pekerjaan yang membutuhkan pelatihan dan penguasaan terhadap suatu pengetahuan khusus. Seseorang yang memiliki suatu profesi tertentu, disebut profesional. Walaupun begitu, istilah profesional juga digunakan untuk suatu aktivitas yang menerima bayaran, sebagai lawan kata dariamatir. Contohnya adalah petinju profesional 
menerima bayaran untuk pertandingan tinju yang dilakukannya, sementara olahraga tinju sendiri umumnya tidak dianggap sebagai suatu profesi.

Adapun suatu karakteristik profesi yang dapat dikatakan profesional. Profesi adalah pekerjaan, namun tidak semua pekerjaan adalah profesi. Profesi mempunyai karakteristik sendiri yang membedakannya dari pekerjaan lainnya. Daftar karakterstik ini tidak memuat semua karakteristik yang pernah diterapkan pada profesi, juga tidak semua ciri ini berlaku dalam setiap profesi:

1. Keterampilan yang berdasar pada pengetahuan teoretis Profesional diasumsikan mempunyai pengetahuan teoretis yang ekstensif dan memiliki keterampilan yang berdasar pada pengetahuan tersebut dan bisa diterapkan dalam praktik.

2. Asosiasi profesional

Profesi biasanya memiliki badan yang diorganisasi oleh para anggotanya, yang dimaksudkan untuk meningkatkan status para anggotanya. Organisasi profesi tersebutbiasanya memiliki persyaratan khusus untuk menjadi anggotanya.

3. Pendidikan yang ekstensif

Profesi yang prestisius biasanya memerlukan pendidikan yang lama dalam jenjang pendidikan tinggi.

4. Ujian kompetensi

Sebelum memasuki organisasi profesional, biasanya ada persyaratan untuk lulus dari suatu tes yang menguji terutama pengetahuan teoretis.

5. Pelatihan institutional

Selain ujian, juga biasanya dipersyaratkan untuk mengikuti pelatihan istitusional dimana calon profesional mendapatkan pengalaman praktis sebelum menjadi anggota penuh organisasi. Peningkatan keterampilan melalui pengembangan profesional juga dipersyaratkan.
6. Lisensi
Profesi menetapkan syarat pendaftaran dan proses sertifikasi sehingga hanya mereka yang memiliki lisensi bisa dianggap bisa dipercaya.

7. Otonomi kerja

Profesional cenderung mengendalikan kerja dan pengetahuan teoretis mereka agar terhindar adanya intervensi dari luar.

8. Kode etik

Organisasi profesi biasanya memiliki kode etik bagi para anggotanya dan prosedur pendisiplinan bagi mereka yang melanggar aturan.

9. Mengatur diri

Organisasi profesi harus bisa mengatur organisasinya sendiri tanpa campur tangan pemerintah. Profesional diatur oleh mereka yang lebih senior, praktisi yang dihormati, atau mereka yang berkualifikasi paling tinggi.

10. Layanan publik dan altruisme

Diperolehnya penghasilan dari kerja profesinya dapat dipertahankan selama berkaitan dengan kebutuhan publik, seperti layanan dokter berkontribusi terhadap kesehatan masyarakat.

11. Status dan imbalan yang tinggi Profesi yang paling sukses akan meraih status yang tinggi, prestise, dan imbalan yang layak bagi para anggotanya. Hal tersebut bisa dianggap sebagai pengakuan terhadap layanan yang mereka berikan bagi masyarakat.

Sedangkan profesionalisme adalah komitmen para profesional terhadap profesinya. Komitmen tersebut ditunjukkan dengan kebanggaan dirinya sebagai tenaga profesional, usaha terus-menerus untuk mengembangkan kemampuan profesional, dan sebagainya. Adapun 4 ciri-ciri profesionalisme antara lain:

1. Memiliki keterampilan yang tinggi dalam suatu bidang serta 
kemahiran dalam menggunakan peralatan tertentu yang diperlukan dalam pelaksanaan tugas yangbersangkutan dengan bidang tadi.

2. Memiliki ilmu dan pengalaman serta kecerdasan dalam menganalisis suatu masalah dan peka di dalam membaca situasi cepat dan tepat serta cermat dalam mengambil keputusan terbaik atas dasar kepekaan.

3. Memiliki sikap berorientasi ke depan sehingga punya kemampuan mengantisipasi perkembangan lingkungan yang terbentang di hadapannya.

4. Memiliki sikapmandiriberdasarkan keyakinan akan kemampuan pribadi serta terbuka menyimak dan menghargai pendapat orang lain, namun cermat dalam memilih yang terbaik bagi diri dan perkembangan pribadinya.

Ada 3 (tiga) hal pokok yang mesti dilakukan dan dipegang oleh seorang pekerja profesional, yaitu:

1) Tidak memaksa

2) Tidak mengiba

3) Tidak berjanji

Bila dilihat inti dari batasan diatas maka dapat dilihat bahwa pengertian profesional tidak dapat dibebaskan dari pengalaman praktik. Timbul pertanyaan bagaimana cara yang dapat memungkinkan seseorang bisa mempersiapkan dirinya menjadi seorang profesional dalam waktu yang relatif singkat? Jawabannya adalah pemagangan yang tepat, bervariasi dan efektif. Untuk mempersingkat masa pemagangan maka studi berbagai kasus baik yang terkait dengan evaluasi masalah serta cara penanggulangan termasuk studi perbandingan dalam berbagai aspek pembangunan akan sangat membantu mempercepat sesorang ahli untuk mencapai tingkat profesional.
Profesi merupakan pekerjaan, namun belum tentu semua pekerjaan adalah profesi. Jelasnya, bahwa profesi merupakan pekerjaan purna waktu. Kemudian, profesional dapat diartikan sebagai sifat mahir dalam suatu profesi. Dalam keterkaitannya, berarti profesi adalah bagian dalam pekerjaan. Dalam kelompok kata $\mathrm{KBBI}$, "profesi" dan "pekerjaan" merupakan kata benda, sedangakan kata "profesional" merupakan kata sifat.

\section{d. Manajemen dan Manajer Petinju Profesional}

\section{a. Manajemen}

Pengertian dan definisi manajemen ialah proses perencanaan pengorganisasian, kepemimpinan, dan pengendalian kegiatan anggota organisasi dan proses penggunaan sumber daya organisasi lainnya untuk mencapai tujuan organisasi yang telah ditetapkan.

Jika kita meninjau dari literatur manajemen, kita akan menemukan istilah manajemen mengandung tiga pengertian yaitu:

1) Manajemen sebagai suatu proses.

2) Manajemen sebagai kolektivitas orang-orang yang melakukan aktivitas manajemen.

3) Manajemen sebagai suatu seni (Art) dan sebagai suatu ilmu pengetahuan (Science).

Pada hakekatnya, perencanaan merupakan proses pengambilan keputusan yang merupakan dasar bagi kegiatan-kegiatan atau tindakantindakan ekonomis dan efektif pada waktu yang akan datang. Proses ini memerlukan pemikiran tentang apa yang perlu dikerjakan, bagaimana dan dimana suatu kegiatan perlu dilakukan serta siapa yang bertanggungjawab terhadap pelaksanaannya.

\section{b. Manajer}

Menurut Kamus Besar Bahasa Indonesia $(\mathrm{KBBI})$, Manajer ialah : 
orang yg mengatur pekerjaan atau kerja sama di antara berbagai kelompok atau sejumlah orang untuk mencapai sasaran. Sedangkan menurut Oxford Learner's Pocket Dictionary: Third Edition (Oxford University Press), Manager (n) person who organizes a business, sports team, etc. (Orang yang mengorganisir bisnis, tim olahraga, dan lain-lain.

4. Kelemahan-Kelemahan Perjanjian Sportentertainment Antara Petinju Profesional Deengan Manajer

a. Kelemahan PerjanjianAntara Petinju Profesional dengan Majajer Dalam Perjanjian Sportentertainment

Perjanjian sportentertainment yang dilakukan antara petinju profesional dengan manajer menggunakan dasar hukum yag terdapat di dalam KUH Perdata yaitu pada pasal 1320 KUHPerdata berbunyi:

1. sepakatmerekayang mengikatkan dirinya;

2. cakap untuk membuat suatu perikatan;

3. suatu hal tetentu;

4. suatu sebab yang halal.

Apabila kelemahan atau keberatan yang dialami oleh atlet dalam menjalankan isi kontraknya, maka diperlukan adanya renegosiasi. Dalam hal ini aspek penting yang di renegosiasikan oleh petinju dengan manager, hal-hal yang dianggap krusial yaitu: kesehatan, keselamatan, pembagian honor, serta perlu kiranya terdapat asuransi yang dapat diterima oleh petinju dalam menjalankan pekerjaanya.

Halyang penting untukmengembalikan hak-hak petinju atas penguasaan dirinya yang dilakukan oleh pihak manager, pertama jaminan kesehatan yang merupakan sesuatu hal yang penting untuk di dapatkan guna kepentingan yang akan datang. Kedua, jangka waktu perjanjian yang dilakukan oleh kedua belah pihak harus terdapat renegosiasi yang dapat dilakukan apabila dalam perjanlananya isi kontrak merugikan salah satu pihak. Ketiga, adanya jaminan keselamatan, hal tersebut penting agar ada saving bagi keberlanjutan dan keberlangsungan masa depan petinju yang meu menjalankan perjanjian sportentertainment tersebut. Keempat pendapatan yang diterima oleh atlet harus lebih adil berimbang dapat memberikan pemasukan bagi keberlangsungan hidup sipetinjutersebut.

Perjanjian sportentertainment yang dilakukan antara petinju dengan manager harus berdasarkan pada keadilan dan hukum.Karena itu hukum tidak boleh kalah dengan kepentingan kelompok tertentu, renegosiasi adalah keniscayaan untuk mengatasi kebutuhan perubahan perjanjian apabila terdapat perselisihan yang timbul ditengah-tengah jalanya suatu kontrak perjanjian. Apa yang dikehendaki oleh petinju profesional, juga dikehendaki oleh pihak manajer. Mereka menghendaki sesuatu yang sama secara timbal balik, yaitu dalam hal hubungan bisnis olah raga tinju. Dengan demikian kesepakatan para pihak untuk membentuk suatu perjanjian merupakan bentuk kesepakatan perjanjian.

1. Pertama, adanya kesepakatan yang dilakukan oleh para pihak yang mengikatkan dirinya

Hal ini mengandung makna bahwa antara petinju dengan manager telah dilakukanya kesepakatan atau ada persesuaian kemauan atau saling menyetujui kehendak masingmasing yang dilahirkan oleh para pihak dengan tidak ada paksaan, kekeliruan, dan penipuan.

Sehubungan dengan syarat kesepakatan yang dilakukan dalam perjanjian sportentertainment terdapat beberapa hal yang merupakan faktor yang dapat menimbulkan cacad pada kesepakatan yang telah dilakukan tersebut, yaitu kecacatan yang dicantumkan dalam Pasal 1321 KUHPerdata yang berbunyi: "Tiada sepakat yang sah apabila sepakat 
itu diberikan karena kekhilafan, atau diperolehnya dengan paksaan atau penipuan".

Dengan demikian, dapat diketahui bahwa perjanjian dikatakan tidak memenuhi syarat kesepakatan kehendak apabila terdapat beberapa unsur yaitu:

\section{a. Adanya kekhilafan}

Kekhilafan dapat terjadi pada orang atau barang yang menjadi tujuan yang diperjanjian oleh pihakpihak yang mengadakan perjanjian. Kekhilafan dalam perjanjian ini berhubungan erat dengan para pihak (orang) yang melakukan perjanjian tersebut.

\section{b. Paksaan}

Dalam suatu perjanjian yang dilakukan oleh petinju dengan manager, paksaan dapat dan mungkin saja terjadi, hal ini berhubungan dengan kekerasan jasmani atau ancaman (akan membuka rahasia) dengan sesuatu yang diperbolehkan hukum yang menimbulkan ketakutan pada seseorang sehingga ia membuat perjanjian.

Jadi, bukanlah paksaan dalam arti absolut, misalnya seseorang yang lebih kuat memegang tangan seseorang yang lebih lemah dan membuat ia mencantumkan tanda tangan pada sebuah perjanjian sebab dalam hal yang demikian itu perjanjian sama sekali tidak terjadi. ${ }^{3}$ Terdapat perbedaan serta persepsi yang dikemukakan diatas berdasarkan dengan pandangan paksaan menurut Subekti, dimana disebutkan bahwa paksaan yang dimaksud adalah paksaan rohani atau paksaan jiwa (psysicis), jadi bukan paksaan badan (fisik). ${ }^{4}$

\section{c. Penipuan}

Penipuan yang dimaksud dalam suatu kontrak adalah suatu upaya tipu muslihat yang digunakan oleh salah satu pihak sehingga menyebabkan kerugian pada pihak lain dalam kontrak tersebut pada saat telah dilakukanya penandatanganan kontrak tersebut. Bahwa satu macam pembohongan saja tidak cukup untuk adanya penipuan ini, melainkan harus serangkaian pembohongan yang di dalamnya hubungan satu dengan yang lainnya merupakan suatu tipu muslihat.Penipuan hanya dilakukan oleh pihak lawan. ${ }^{5}$

2. Kedua, para pihak cakap untuk membuat suatu perikatan.

Hal ini berdasarkan Pasal 1329 KUHPerdata adalah: "Setiap orang adalah cakap untuk membuat perikatan-perikatan, jika ia oleh undang-undang tidak dinyatakan tak cakap".Sedangkan yang dimaksud dengan tidak cakap untuk membuat suatu perjanjian berdasarkan Pasal 1330 KUH Perdata adalah:

a. Orang-orang yang belum dewasa, yaitu sebagaimana yang telah diatur dalam Pasal 330 KUH Perdata dimana dijelaskan: "Belum dewasa adalah mereka yang belum mencapai umur genap dua puluh satu tahun, dan tidak lebih dahulu telah kawin".

b. Mereka yang ditaruh di bawah pengampuan. Hal ini merupakan salah satu golongan orang-orang yang dianggap tidak cakap untuk membuat perjanjian adalah orang-orang yang ditaruh di bawah pengampuan. Menurut Pasal 443 KUH Perdata, orang-orang yang diletakkan di bawah pengampuan

Buku III (Hukum Perikatan, 1993, KUH Perdata Alumni, Bandung, hlm. 76

4 R. Subekti, 1976. Hukum Perjanjian, cet. IV, Intermasa, Jakarta, hlm. 23
Wirjono Prodjodikoro, 1979, Asas-asas Hukum Perjanjian, Sumur Bandung, Jakarta, hlm. 84 
adalah: "Setiap orang dewasa yang selalu berada dalam keadaandungu, sakit otak atau mata gelap, dan boros".

c. Orang-orang perempuan, dalam hal-hal yang ditetapkan oleh undangundang. Sesuai dengan ketentuan yang terdapat di dalam Pasal 108 ayat (2) KUH Perdata berbunyi, "Seorang istri, biar ia telah dikuasakan oleh suaminya, untuk membuat suatu akta, atau untuk mengangkat sesuatu perjanjian sekalipun, namun tidaklah ia karena itu berhak, menerima sesuatu pembayaran, atau member perlunasan atas itu, tanpa izin yang tegas dari suaminya". Selain itu, juga diperkuat dengan adanya pasal $110 \mathrm{KUH}$ Perdata yang berbunyi, "Seorang istri, biar ia kawin diluar persatuan harta kekayaan, atau telah berpisahan dalam hal itu, biar ia melakukan sesuatu mata pencaharian atas usahasendiri sekalipun, namun tak bolehlah ia menghadap di muka Hakim tanpa bantuan suaminya".

d. Orang yang dilarang oleh undang-undang untuk melakukan perbuatan tertentu. orang-orang tertentu yang oleh undang-undang tertentu dianggap tidak wenang membuat kontrak tertentu dengan cara tertentu atau dengan pihak tertentu (Pasal 1330 ayat (3) KUH Perdata).

3. Ketiga, yaitu adanya Suatu hal tertentu merupakan syarat sahnya suatu perjanjian adalah adanya unsur suatu hal tertentu.
Yang dimaksudkan dengan suatu hal tertentu adalah objek dari suatu perjanjian.Suatu perjanjian haruslah mempunyai objek (bepaald onderwerp) tertentu, sekurangkurangnya dapat ditentukan.

4. Keempat, yaitu adanya sebab yang halal

Dalamperjanjiansportentertainment yang dilakukan antara petinju profesional dengan manajer menggunakan dasar hukum yag terdapat di dalam $\mathrm{KUH}$ Perdata, maka sebab yang halal merupakan suatu keharusan, hal ini sangat berkaitan erat dengan sarat sahnya suatu perjanjian.

\section{Rekonstruksi Perjanjian Sportentertainment Yang Berbasis Nilai Keadilan.}

Mewujudkan nilai kemnafaatan sesuai ajaran dalam Al-Qur'an, yaitu diantaranya Ad-Darar yuzal (bahaya harus dihilangkan) ${ }^{6}$ Melakukan perumusan untuk terobosan dimasa yang akan datang mengenai perjanjian sportentertainment. Sebelumnya telah dijabarkan mengenai kondisi \& kelemahan perjanjian sportentertainment khususnya antara petinju dengan manajer yang masih terdapat celah-celah kelemahan hukum yang dapat menciderai keadilan.

a. Pentingnya Perjanjian Tertulis Dalam Sportentertainment Antara Petinju Profesional Dengan Manajer.

Berdasarkan Pasal 54 ayat (1) Undang-undang Nomor 13 Tahun 2003, perjanjian kerja yang dibuat secara tertulis sekurang kurangnya memuat:

a. nama, alamat perusahaan, dan jenis usaha

b. nama, jenis kelamin, umur, dan alamat pekerja/ buruh

c. jabatan atau jenis pekerjaan

d. tempat pekerjaan dilakukan

e. besarnya upah dan cara pembayarannya

6 Achmad Ali, 2012, Menguak Teori Hukum dan Teori Peradilan, Cet IV, Prenada Media Goup, Jakarta, hlm. 216 - 217. 
f. syarat-syarat kerja yang memuat hak dan kewajiban pengusaha dan pekerja/ buruh

g. mulai dan jangka waktu berlakunya perjanjian kerja

h. tempat dan tanggal perjanjian kerja dibuat

i. anda tangan para pihak dalam perjanjian kerja.

b. Wanprestasi dan Prosedur Penyelesaiannya dalam Perjanjian Sportentertainment antara Petinju Profesional dan Manajer

Dalam perjanjian ada dua subjek hukum, yaitu pihak yang berkewajiban untuk melaksanakan suatu prestasi dan pihak yang berhak atas suatu prestasi. Dalam pemenuhan suatu prestasi atas perjanjian yang telah dibuat oleh para pihak tidak jarang pula terdapat pihak yang lalai melaksanakan kewajibannya atau tidak melaksanakan seluruh prestasinya, hal inilah yang disebut dengan keadaan wanprestasi. Setiap wanprestasi mempunyai akibat yang sangat penting, dalam hal perjanjian sportentertainment antara petinju profesional dan manajer harus diketahui terlebih dahulu apakah benar diantara pihak yang melakukan perjanjian ada melakukan cidera janji atau tidak.

c. Pembaharuan Hukum Perjanjian

Sportentertainment Antara Petinju

Profesional Dan Manajer Yang

Berbasis Nilai Keadilan

Perjanjian yang baik dan ideal hendaknya mencakup seluruh unsur-unsur perjanjian itu sendiri. Di mana perjanjian tersebut mengikat kepada pihak-pihak yang tertera/terikat dalam surat perjanjian dengan kepastian hukum dimana perjanjian tersebut harus dipatuhi yang asasnya dikenal dengan pacta sunservanda.

1. Pacta Sunservanda dalam

Perjanjian Sportentertainment

Pada dasarnya asas ini berkaitan dengan kontrak atau perjanjian yang dilakukan diantara para individu, yang mengandung makna bahwa: a. perjanjian merupakanundangundang bagi para pihak yang membuatnya, dan

b. mengisaratkan bahwa pengingkaran terhadap kewajiban yang ada pada perjanjian merupakan tindakan melanggar janji atau wanprestasi

Dalam Islam juga terdapat dalam petikan Q.S Al Isra ayat 34 : ".... dan penuhilah janji, sesungguhnya janji itu akan diminta pertanggung jawabannya..." Dari sekelumit kalimat tersebut bila dikaitkan dengan perjanjian sportentertainment, maka barang siapa yang telah membuat janji (perjanjian) mempunyai kewajiban untuk melaksanakan apa yang dijanjikan atau diperjanjikan, dalam hal ini kedua belah pihak antara petinju dan manajer melaksanakan isi perjanjian.

2. Perjanjian Sportentertainment Antara Petinju Profesional Dan Manajer Yang Ideal

Memahami unsur-unsur perjanjian sangat penting agar dapat diketahui dengan pasti apakah yang dihadapi termasuk perjanjian atau bukan, berikut penulis jabarkan penjelasan dari tiap unsur:

1) Kata Sepakat Dari Dua Pihak atau Lebih

Dalam hal ini kata sepakat dapat dimaknakan sebagai pernyataan kehendak. Suatu perjanjian hanya akan terjadi apabila terdapat dua pihak atau lebih yang saling menyatakan kehendak untuk berbuat sesuatu. Inilah yang menjadi perbedaan pokok antara perjanjian dengan perbuatan hukum sepihak.

2) Kata Sepakat yang Tercapai Harus Bergantung Kepada Para Pihak

Kehendak dari para pihak saja tidak cukup untuk melahirkan suatu perjanjian. Kehendak tersebut harus dinyatakan. Sehingga setelah para 
pihak saling menyatakan kehendaknya dan terdapat kesepakatan diantara para pihak, terbentuklah suatu perjanjian diantara mereka

3) Keinginan atau Tujuan Para Pihak untuk Timbulnya Akibat Hukum

Suatu janji atau pernyataan kehendak tidak selamanya menimbulkan akibathukum. Terkadang suatu pernyataan kehendak hanya menimbulkan kewajiban sosial atau kesusilaan. ${ }^{7}$ Misalnya janji diantara beberapa orang untuk menonton suatu pertandingan tinju, apabila satu diantara mereka tidak dapat hadir untuk menepati janjinya maka orang tersebut tidak dapat digugat dihadapan pengadilan.

4) Akibat Hukum untuk Kepentingan Pihak yang Satu dan Atas Beban yang Lain atau Timbal Balik

Akibat hukum yang terjadi adalah untuk kepentingan pihak yang satu dan atas beban terhadap pihak yang lainnya atau bersifat timbal balik. ${ }^{8} \mathrm{Di}$ sini yang perlu diperhatikan adalah akibat hukum dari suatu perjanjian hanya berlaku bagi para pihak dan tidak boleh merugikan pihak lain. Dalam perkembangan doktrin ilmu hukum dikenal adanya tiga unsur dalam Perjanjian. Diantaranya unsur isinya sesuai dengan kesepakatan dan nantinya mengikat kedua belah pihak. $^{9}$

5) Dibuat dengan Mengindahkan Ketentuan Perundang-undangan Pada umumnya para pihak bebas menentukan bentuk perjanjian, namun dalam beberapa perjanjian tertentu undang-undang telah menentukan bentuk yang harus dipenuhi. Misalnya untuk pendirian perseroan terbatas harus dibuat dengan akta notaries.

Semestinya dalam membuat surat perjanjian sportentertainment hendaknya dibuat seadil-adilnya bagi para pihak yang tertera di surat perjanjian, dalam hal ini adalah antara petinju dan manajer. Adil pada hakikatnya berarti kita memberikan kepada siapa saja yang menjadi haknya. Karena semua orang sarna nilainya sebagai manusia, maka tuntutan paling dasariah keadilan ialah perlakuan yang sama terhadap semua orang, tentunya dalam situasi yang sarna. Jadi prinsip keadilan adalah mengungkapkan kewajiban untuk memberikan perlakuan yang sama terhadap semua orang dalam situasi yang masa dan untuk menghormati hak semua pihak yang bersangkutan.

Jadi dalam pembuatan surat perjanjian sportentertainment antara petinju profesional dan manajer dengan berbasis nilai keadilan diperlukan tata cara dan syaratsyarat dalam pembuatannya sehingga sah dan berkekuatan hukum yang mengikat. Dalam Pasal $1338 \mathrm{KUH}$ Perdata menyebutkan bahwa "Semua perjanjian yang dibuat secara sah berlaku sebagai undang-undang bagi mereka yang membuatnya" .

Berdasarkan uraian diatas maka penulis susun rekonstruksi nilai perjanjian sportentertainment yang berbasis nilai keadilan adalah perlindungan hukum yang adil antara petinju professional dan menejer yang meliputi : imbalan, lama kontrak, pilihan hukum penyelesaian perselisihan kontrak serta hak dan kewajiban.

\footnotetext{
7 Herlien Budiono, 2010, Ajaran Umum Hukum Perjanjian dan Penerapannya di Bidang Kenotariatan, Citra Aditya, Bandung, hlm. 9-10

8 Ibid, hlm. 10-11

9 Ahmadi Miru, 2007, Hukum Perjanjian dan Perancangan Perjanjian, Raja Grafindo Persada, Jakarta, hlm.31-32
} 
Tabel. 1. Pembaharuan Hukum Pasal 1320 KUH Perdata

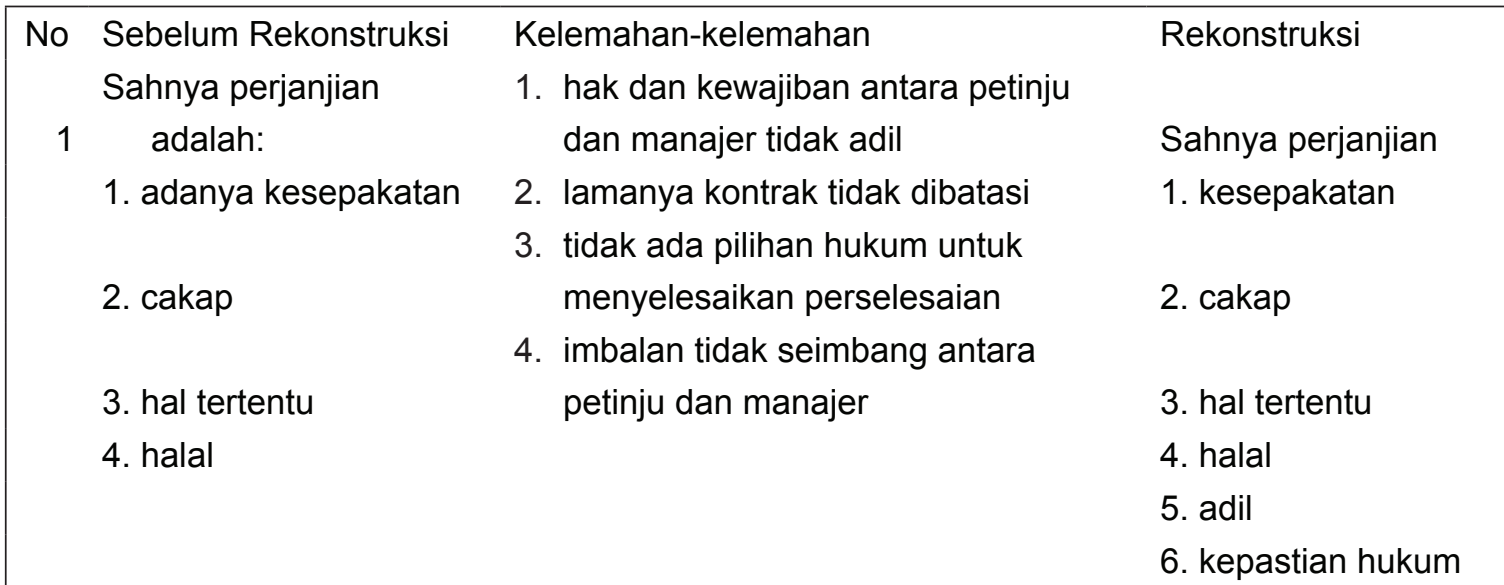

\section{Penutup}

\section{Simpulan}

Kesimpulanyang dapat disarikan darikajian ini, pertama, perjanjian sportentertainment antara petinju professional dengan Manajer saat memiliki banyak kelemahaan yaitu: Bagi atlet petinju professional, lamanya kontrak serta pilihan hukum untuk menyelesaikan perselisihan. Dalam perjanjian tersebut manajer seharusnya memberikan keleluasaan bagi petinju seharusnya porsinya lebih besar bukan lebih kecil dari aspek keadilan hukum, perjanjian sportentertainment dapat dikatakan gugur apabila mempertontonkan praktek ketidakadilan ada pembagian yang tidak berimbang. Kedua, Rekonstruksi nilai perjanjian sportentertainment antara petinju profesional dengan manajer yang berbasis nilai keadilan, berupa perlindungan hukum yang adil dan seimbang antara petinju professional dan manajer. Pentingnya perjanjian tertulis, dengan adanya perjanjian tertulis maka para pihak harus melaksanakan apa yang telah diperjanjikan atau apa yang telah menjadi kewajibannya dalam perjanjian tersebut.
Serta adanya kewajiban memenuhi apa yang dijanjikan.

Dalam kajian ini hanya terbatas pada kelemahan-kelemahan perjanjian sportentertainment dan pembaharuan perjiannya di masa yang akan datang.

\section{SARAN}

Antara kedua belah pihak dalam perjanjian sportentertainment antara petinju professional dengan managemen perlu memuat kriteria-kriteria serta mengatur secara detail permasalahan-permasalahan yang kemungkinan besar terjadi antara kedua belah pihak yang ada dalam perjanjian tersebut. Selain itu, pendidikan serta pemahaman akan pentingnya hukum perjanjian juga menjadi suatu kendala yang cukup serius dimana tidak jarang para pihak atau salah satu dari para pihak yang membuat perjanjian tersebut kurang mengerti dan memahami teknik dalam menyusun perjanjian, sehingga memungkinkan terjadi penipuan yang merugikan salah satu pihak yang melakukan perjanjian tersebut. 


\section{DAFTAR PUSTAKA}

Abdul Kadir Muhammad. 1982. Hukum Perikatan, Bandung : Alumni

Achmad Ali. 2012. Menguak Teori Hukum dan Teori Peradilan, Cet IV. Prenada Media Goup. Jakarta.

Ahmadi Miru. 2007. Hukum Perjanjian dan Perancangan Perjanjian. Raja Grafindo. Jakarta.

Herlien Budiono. 2010. Ajaran Umum Hukum Perjanjian dan Penerapannya di Bidang Kenotariatan. Citra Aditya. Bandung.

Mariam Darus Badrulzaman. 1993. KUH Perdata Buku III (Hukum Perikatan dengan Penjelasan). Alumni. Bandung.

R. Subekti. 1976. Hukum Perjanjian. cet. IV. Intermasa. Jakarta.

Wirjono Prodjodikoro. 1979. Asas-asas Hukum Perjanjian. Sumur Bandung. Jakarta. 